\title{
The Application of Shariah Principle in E-commerce Transaction: A Model Development
}

\author{
Mohd Zulkifli Muhammad ${ }^{1}$, Tamrin Amboala ${ }^{2}$, Muhammad Zulfaris Mohd Salleh ${ }^{1}$, Azwan Abdullah ${ }^{1}$, Siti Nurzahira \\ Che Tahrim ${ }^{1} \&$ Noorshella Che Nawi ${ }^{1}$ \\ ${ }^{1}$ Universiti Malaysia Kelantan, Malaysia \\ ${ }^{2}$ Universiti Malaysia Sabah, Malaysia \\ Correspondence: Mohd Zulkifli Muhammad, Universiti Malaysia Kelantan, Malaysia.
}

Received: May 1, 2019

doi:10.5430/rwe.v10n2p84
Accepted: June 1, 2019

Online Published: July 8, 2019

URL: https://doi.org/10.5430/rwe.v10n2p84

\begin{abstract}
Issues concerning purchasing on-line, the medium of transaction via on-line or Internet, e-payment mode are among new challenges that require Islamic scholars and researchers to broaden the scope of definition of Shariah compliance e-commerce transaction. As Malaysia is heading towards e-commerce and purchasing on-line has no longer a new trend; the challenges arise for solution in accordance with Shariah principles. This paper will propose a model that comprises several components namely, the core Shariah component itself, sound technological means and regulatory body that supports e-commerce transactions.
\end{abstract}

Keywords: E-commerce transaction, E-payment, Islamic finance, Shariah principles

\section{Introduction}

The convergence of IT and commerce have brought more complex levels of Islamic business and commerce ethics that require the Islamic jurisprudents to expand their tools of evaluation and analysis beyond the traditional context. With a comprehensive approach that taking into account regulations and the existing technological tools brought into the Shariah's model, this article seeks and develops an understanding on how to provide alternative solution to the conventional and unislamic e-commerce transaction. Undeniably, e-commerce is allowed in Islam as long as it complies with requirements stipulated by Islamic law of contract namely (i) form, (ii) contracting parties and (iii) subject matter. This is to ensure that the main objective of commerce in Islam which is protecting interests and eliminating harms of parties involved in a commercial-related transaction, could be successfully achieved (Marjan et al., 2013).

Nonetheless, online transaction has postulated several main challenges with from Shariah point of view which will be discussed here namely the security, legality of the contract, issues of anonymity, gharar and riba. Islam accords the importance to the trading sector as source of wealth and the roles its play to the development of the country and the ummah as a whole. In this regard, the holy Quran abounds with many references to the trade and commercial activities such as in An-Nisa' (4:29), Al-Muthaffifin (83:1) and Ali Imran (3:130). Regardless of the mode of conducting business, every Muslim must be faithful and God-fearing in conducting business. He must ensure that he is in lined with the Quran and Sunnah (Norazlina et al., 2004; Chang, 2017).

Few studies have attempted to develop an appropriate model to suit current Islamic financial system such as eXtensible Access Control Markup Language (XACML) and Intermediate Shariah Transaction Party (ISTP) (Tamrin et al., 2015; Chiang \& Tzou 2018). Considering the complexity of the way businesses and commerce carrying out the transaction today, it is very crucial to create an entirely new model and methods for a modern Islamic transaction for the ummah. By combining several methods such as information technological approach, e-commerce infrastructure, regulatory framework, with some adjustment and modification in order to fit the Shariah's principles is deemed necessary (Izzat \& Mohammad, 2015; CHE \& Sundjo 2018).

\section{Core Shariah Requirements}

Based on the nature of the transaction, e-commerce falls into the category of Bai-Salam. Bai-Salam is a type of transaction in which buying and selling always take place in advance. According to Prophet s.a.w. said, "Whoever 
paid in advance, make sure you fixed the measurement and time limit". The conditions applied to the Bai-Salam can be broken further as follows, namely, price fixed with Ijab (offer) and Qabul (acceptance), pay in cash or goods, pay in same Majlis, products have to clearly identified, delivery date have to be fixed (Nor Azah \& Al-Hassan, 2016; Chima \& Kasim 2018).

\subsection{Legality of On-line Contract}

The formation of contract requires two parties: one offers the contract then another party who will accept the offer. The offer is the proposal which is made to show his or her willingness to form a contract and in turn, the later response from the other party to prove his or her willingness to the offer. The terms and conditions of the contract can be easily communicated on line but issues arise pertaining to the meeting place. The idea of setting place in Islamic commercial legal system is required to extend the validity of the offer over a certain period of time in which the acceptance must be made within the designated period. A part from giving option for annulling the sale at any time before separation the meeting place alleviate anonymity concern. Failure in addressing the issue of anonymity will bring in issues of security of the transaction itself (Siddiqi, 2000; Chowdhury Habibullah \& Nahar 2018).

\subsection{E-payment Methods}

Debit card and credit card are two most common payments in e-commerce. Debit card is regarded the better method of payment from Islamic point of view compared to credit card since there is no room for interest (usury) involved. It only replicates the real payment from auto teller machine on e-commerce transaction and payment is transferred almost immediately from consumer's bank account to the merchant's account.

\subsection{Issues of Riba'}

Imposing a percentage on the amount of money used by credit cards is Riba (usury and interest) in itself, whether such a percentage is taken as a charge service and administrative expense or due to delay in settlement. Both forms are a usurious loan and the most well-known form of Riba of non-Islamic systems. However, how does Islam accept the concept of credit card as a medium of on-line payment? What are the underlying principles required by Shariah in the functionality of credit card? Islamic credit card is the substitute for conventional interest-based credit cards. Islam allows the use of credit card as long as it does not involve the element of interest. In Malaysia, the doctrine of Bay al-Inah is recognized and used to validate the credit card transaction (Cokgezen \& Kuran, 2015).

The Bay al-Inah contract works on the basis of two (2) separate agreements, namely Bay al-Mutlak (cash sale) and Bay Bithaman Ajil (deferred sale) (Johan \& Putit, 2016). The former is the bank's agreement to sell an item to the customer at an agreed price, while the latter agreement covers the customer selling back to the bank at a lower price. The difference is the bank's profit on the transaction and is a predetermined amount. There is no penalty charged to the customer and for the unutilized financing amount the customer is legible for rebate (Khir et al., 2008).

\subsection{Issues of Gharar (Uncertainty)}

The anonymity of Internet users including traders contribute to the complexity of defining gharar in its new dimension. It used to happen in which the subject matter is concealed from the buyer without he or she knowing exactly its future result. In the sense of on-line transactions there are also three major concerns pertaining to gharar; the uncertainties over the products or the services itself, uncertainties over pricing, delivery and deferment (Muhammad Kholifatul, 2016).

Hence, Islamic business and commerce ethics require the sellers to clearly define the products offered, for instance the image of the products must be displayed clearly on the screen with their detailed specifications, the prices, the mode of delivery and payments. Secondly both contracting parties; sellers and buyers must able to exchange the message in order to achieve conformity in the agreement that bind them together. In addition, seller may add the additional contract such as option to refund or return the products (khiyar) (Al-Arif, 2013).

\section{Sound Technological Means}

Securing transaction online must fulfill two main requirements, first concerning how to protect the data from the unauthorized parties (confidentiality) and how to guarantee the integrity of the transaction itself. Confidentiality ensures that the data travels on-line only be received and access by the authorized party(s). On the other hand, Trusted Network Interpretation defines that the integrity ensures that computerized data are the same as those in source documents.

\subsection{The Application of Digital Signature and Certified Authority to Resolve Anonymity Concern}

The article proposes Digital Signature to be used in order to resolve anonymity in relation with the security and the 
validity of the transaction from Islamic legal system. Though securing data from disclosure by the unauthorized party will ensure confidentiality, it will not protect the data from repudiation. There is a compelling need that for the message to be protected from repudiation. Digital signature is one of mechanism for authentication. It allows a receiver to know a sender of a given electronic document in the same way that conventional signature allow a receiver to know the sender of a written document and cannot be forged (Comer, 2007). The application of digital signature enables the condition of Ijab and Qabul for both parties' (buyer and sellers) to be fulfilled in Bai-Salam (Johan et al., 2017).

Certificate Authority (CA) is also involved to resolve any possible conflict concerning the authentication and the confidentiality of the transaction. The trusted third party or the certificate authority will ensure that the message received in a form when it was sent. The general idea is that a certificate authority is trusted, so users can delegate the construction, issuance, and acceptances as well as revocation of certificates to the authority.

3.2 The Application of Session Key to Resolve Time Validity Period in Meeting Time and Place in Shariah's Principle

The validity period in meeting place can be resolved with an authorization and authorization technique in Authentication Protocols by using session key. The difference between authentication and authorization is deal with whether a person is communicating with a specific process whilst whether or not the person permitted to do the specific process or activity. Though the application of session key is mainly used for authorization can be expanded to be validate time validity. Once the communication is terminated, the session key can be cheaply discarded. The application of session key hence resolve issues of meeting place and time for contracting parties in Islamic transaction. This is the same condition that needs to be met in the Bai-Salam in which payment need to be settled in the same Majlis (Ainnur Hafizah et al., 2013).

\section{Regulatory Body}

\subsection{Shariah Advisors}

Bank Negara Malaysia (BNM) has introduced guidelines on the governance of Shariah Advisory Council (SAC), but it shows that SAC in Malaysia role and function are focusing only in financial institutions like banking and Takaful. There are crucial needs to define the roles of Shariah advisors in other industry like e-commerce. A Shariah body in industry which to be known as a SAC will play a complementary role to the SAC of Bank Negara Malaysia (Izzat \& Mohammad, 2015).

Currently e-commerce transactions are beyond duties and responsibilities of SAC. As the paper suggests that the framework for Shariah compliance require comprehensive approach in terms of the legality of the transaction itself from the Shariah point of view, sound technological approach, and the existing enactment and law that support the e-commerce. Hence, the paper suggests SAC to include the e-commerce transaction into their supervision. Instead of a regulatory body, SAC may act as an advisory council for Islamic e-commerce transaction for BNM. Extensive research need to be undertaken on how SAC will influence the Islamic online transaction but initially the main aim of the inclusion is to promote the Shariah based transaction into the e-commerce transaction.

\section{Conclusion}

The article has highlighted extensive discussion pertaining to e-commerce transactions in order for them to comply with Shariah principles. In addition comprehensive approach is critically required for the implementations in a real world. The article include all relevant mechanism that include sound internet technological approach, legislation and enforcement of law, regulatory body such as SAC and Bank Negara, e-commerce players such as banks and financial institutions and last but not least the existing enactments and laws pertaining to on-line transaction. Besides, this article may also serve as a general guidance for e-commerce for more than one billion Muslim ummah globally.

\section{Acknowledgement}

The authors would like to thanks the Universiti Malaysia Kelantan (UMK) for funding the research grant SGJP, R/MyRA/A01.00/00677A/003/2017/000394.

\section{References}

Ainnur Hafizah, A.M., Mohd Zulkifli, M., Tamrin, A., \& Mohd Sarwar, E.A. (2013). Bai as-salam and e-commerce: A comparative analysis from Shariah perspectives. Presented to The 2nd Applied International Business Conference, Labuan, Malaysia. 
Al-Arif, M.N.R. (2013). Penjualan on-line berbasis media sosial dalam perspektif ekonomi Islam. Ijtihad: Jurnal Wacana Hukum Islam dan Kemanusiaan, 13(1), 33-48. https://doi.org/10.18326/ijtihad.v13i1.33-48

Chang, P. (2017). The Importance Performance Analysis of Taiwan tourism mobile marketing. Journal of Tourism Management Research, 4(1), 12-16. https://doi.org/10.18488/journal.31.2017.41.12.16

Che, G. N., \& Sundjo, F. (2018). Determinants of Female Labour Force Participation in Cameroon. International Journal of Applied Economics, Finance and Accounting, 3(2), 88-103. https://doi.org/10.33094/8.2017.2018.32.88.103

Chiang, P.-M., \& Tzou, H.-I. (2018). The Application Of Differential Person Functioning On The Science Literacy Of Taiwan Pisa 2015. Humanities \& Social Sciences Reviews, 6(1), 08-13. https://doi.org/10.18510/hssr.2018.612

Chima, P., \& Kasim, U. (2018). Public-private partnership as a strategy for e-governance funding in Africa: The gains and the pains. International Journal of Public Policy and Administration Research, 5(2), 37-47. https://doi.org/10.18488/journal.74.2018.52.37.47

Chowdhury, T. S., Habibullah, M., \& Nahar, N. (2018). Risk and return analysis of closed-end mutual fund in Bangladesh. Journal of Accounting, Business and Finance Research, 3(2), 83-92. https://doi.org/10.20448/2002.32.83.92

Çokgezen, M., \& Kuran, T. (2015). Between consumer demand and Islamic law: The evolution of Islamic credit cards in Turkey. Journal of Comparative Economics, 43(4), 862-882. https://doi.org/10.1016/j.jce.2015.07.005

Comer, D. E. (2007). The internet book: Everything you need to know about computer networking and how the internet works. New Jersey: Pearson Prentice Hall.

Izzat, A., \& Mohammad, Z. (2015). Building an Islamic financial information system based on policy managements. Journal of King Saud University-Computer and Information Sciences, 27, 364-375. https://doi.org/10.1016/j.jksuci.2014.11.001

Johan, Z. J., \& Putit, L. (2016). Conceptualizing the influences of knowledge and religiosity on Islamic credit card compliance. Procedia Economics and Finance, 37, 480-487. https://doi.org/10.1016/S2212-5671(16)30155-1

Johan, Z. J., Dali, N. R. S. M., Suki, A. A., \& Hafit, N. I. A. (2017). Customers' intention towards Shariah compliant credit cards: A pilot study. International Journal of Academic Research in Business and Social Sciences, 7(4), 772-799. https://doi.org/10.6007/IJARBSS/v7-i4/2887

Khir, K., Gupta, L., \& Shanmugam, B. (2008). Islamic banking: A practical perspective. Selangor, Malaysia: Pearson.

Marjan, M., Muhd Rosydi, M., Mohd Adam, Husnayati, H, Mohamed Jalaldeen, M.R., \& Kalthom, A. (2013). Building trust in e-commerce from an Islamic perspective: A literature review. American Academic \& Scholarly Research Journal, 5(5), 161-168.

Muhammad Kholifatul, I., Ardiansyarh, Y., \& Budi, H. (2016). Shari'ah-compliant e-commerce models and consumer trust. Al-Iqtishad: Jurnal Ilmu Ekonomi Syariah (Journal Of Islamic Economics), 8(2), 243-254. https://doi.org/10.15408/aiq.v8i2.2913

Nor Azah, J., \& Al-Hasan, A. (2016). Online dropship for business transaction in Malaysia: Views from muslim scholars. International Journal of Islamic Business, 1(1), 13-28.

Norazlina, Z., Fauziah, O., \& Siti Hartini, M. (2004). E-Commerce from an Islamic perspective. Electronic Commerce Research and Applications, 3, 280-293. https://doi.org/10.1016/j.elerap.2004.01.002

Shelly, G. B., Cashman, T. J., Napier, H. A., Judd, P. J., \& Kaufmann, E. (2004). Discovering the internet: Complete concepts and techniques. Connecticut: Thomson.

Siddiqi, A. H. (2000). Shahih Muslim, tradition no. 3658, Kitab Bhavan.

Tamrin, A., Ainnur Hafizah, A.M., Mohd Zulkifli, M., Mohamad Fauzan, N., \& Roslina, O. (2015). Development method for Shariah compliant e-commerce payment processing. International Journal of Computer Theory and Engineering, 7(5), 408-415. https://doi.org/10.7763/IJCTE.2015.V7.995 